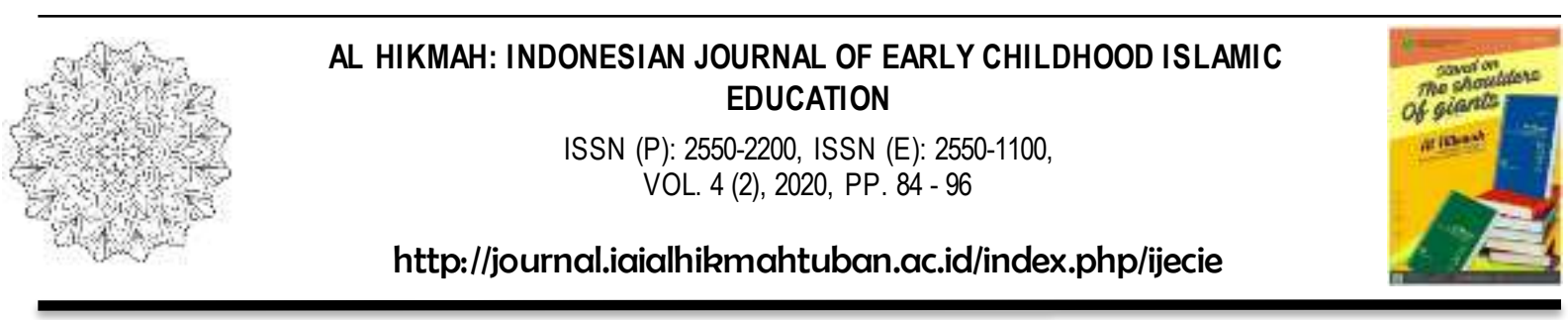

\title{
PENINGKATAN KOGNITIF MELALUI METODE BERNYANYI DI RA SUNAN AMPEL PASURUAN
}

\author{
Aam Subekti ${ }^{1}$, Erynka Iryaning Aulya ${ }^{2}$, Laili Karomah ${ }^{3}$, Hernik Farisia $^{4}$ \\ ${ }^{1,2}$ Universitas Islam Negeri Sunan Ampel Surabaya, \\ ${ }^{2,3}$ RA Sunan Ampel Surabaya
}

\begin{abstract}
Abstrak
Metode bernyanyi sudah lama digunakan sebagai metode belajar untuk anak usia dini karena pada dasarnya bernyanyi adalah bakal alamiah yang dimiliki setiap individu sejak lahir dan dapat diintegrasikan dalam pembelajaran, seperti yang disampaikan Masitoh, dkk (2007:11.8). Tujuan dari penelitian ini adalah untuk memaparkan peningkatan kognitif anak melalui bernyanyi dalam pembelajaran di kelas B RA Sunan Ampel Pasuruan. Metode yang digunakan yaitu eksperimen dan observasi hasil belajar. Kami memberikan tugas menghafal kosa kata Bahasa arab dengan lagu dan Bahasa inggris tanpa lagu dengan pengumpulan tugas berupa video atau pesan suara. Hasil akhirnya 7 dari 15 anak mengumpulkan tugas lagu Bahasa arab terlebih dahulu di hari pertama dan mulai mengumpulkan tugas hafalan Bahasa inggris di hari kedua. Dapat disimpulkan bahwa kemampuan kognitif anak kelas B RA Sunan Ampel Pasuruan meningkat melalui metode bernyanyi.

Kata Kunci: Perkembangan Kognitif, Metode Bernyanyi
\end{abstract}

\section{Abstract}

The singing method has long been used as a learning method for early childhood because basically singing is a natural gift that every individual has from birth and can be integrated into learning, as stated by Masitoh, et al (2007: 11.8). The purpose of this study was to describe children's cognitive enhancement through singing in class B RA Sunan Ampel Pasuruan. The method used is experiment and observation of learning outcomes. We give the task of memorizing Arabic vocabulary with songs and English without songs by collecting assignments in the form of videos or voice messages. The end result is that 7 out of 15 children collect Arabic song assignments on the first day and start collecting English memorization assignments on the second day. It can be concluded that the cognitive abilities of class B children RA Sunan Ampel Pasuruan improved through the singing method.

Keywords: Cognitive Development, Singing Method

\section{PENDAHULUAN}

Pendidikan Anak Usia Dini (PAUD) adalah suatu upaya pembinaan yang ditujukan melalui pemberian rangsangan pendidikan untuk membantu pertumbuhan dan perkembangan jasmani dan rohani agar anak memiliki kesiapan dalam memasuki pendidikan lebih lanjut (Undang-undang Nomor 20 Tahun 2003 tentang Sistem Pendidikan Nasional). Pendidikan Anak Usia Dini 
(PAUD) merupakan pendidikan yang paling mendasar yang menempati posisi yang sangat strategis dalam pengembangan sumber daya manusia.

Pendidikan anak usia dini sangat penting untuk menjadi aset suatu bangsa, karena pendidikan dimulai dari usia dini, baik didapatkan dikelas ataupun dirumah. Dikelas anak mendapat bimbingan yang lebih fokus untuk peningkatan 6 aspek perkembangan anak, diantarnya dengan metode bernyanyi anak lebih percaya diri jika dihadapkan didepan banyak orang.

Kamtini mengemukakan, "Bernyanyi merupakan sarana pengungkapan pikiran dan perasaan, sebab kegiatan bernyanyi penting bagi pendidikan anakanak sesuai dengan aspek perkembangan. Bernyanyi adalah kegiatan menyenangkan yang memberi kepuasan kepada anak- anak. Anak telah memiliki dasar apresiasi secara alami sejak bayi, bayi tertidur pulas dengan nyanyian ibunya, beranjak besar nyanyian demikian sering di dengarnya, walaupun ia sendiri belum mengerti maknanya, namun hatinya senang, rasa tentram dan rasa bahagia. Kemudian ia mempelajari nyanyian, irama, melodi, dan syairnya, sampai ia mahir menyanyikan sendiri, oleh karena itu pembiasaan penyerapan seni adalah penting supaya kognitif anak bisa berkembang. Setiap anak akan mengalami fase berifikir, kemampuan ini yang menentukan cepat tidaknya atau terselesaikan tidaknya suatu masalah yang sedang dihadapi, melalui kemampuan intelegensi yang dimiliki oleh seorang anak, maka anak akan terbiasa dengan situasi tersebut dan jika ada masalah yang akan dihadapi anak akan merasa tenang.

Ketika anak menghadapi suatu masalah seperti tugas sekolah yang anak terkadang tidak mampu untuk mengerjakan sendiri, anak akan meminta bantuan kepada orang-orang terdekat, dan jika anak sudah mengerti apa yang harus anak lakukan anak akan melakukan dengan percaya diri sesuai dengan penjelasan para hali dibawah ini, Banyak ahli yang menjelaskan definisi kemampuan seperti Wijaya menjelaskan, 'kemampuan merupakan kesanggupan menyelesaikan suatu hal dengan baik". Sejalan dengan pendapat Wijaya, Sujono dkk menjelaskan, "kemampuan merupakan perilaku yang rasional untuk mencapai tujuan yang disyaratkan sesuai dengan kondisi yang diharapkan”. 
Beberapa ahli psikologi yang berkecimpung dalam dunia pendidikan mendefinisikan intelektual atau kognitif dengan berbagai istilah. Kognitif adalah kemampuan untuk menyesuaikan diri dengan lingkungan, mencerna sesuatu dengan berfikir dan juga menghafal, dan juga kognitif juga untuk memproses informasi yang disediakan oleh indra intelektual ditambah dengan pengetahuan dan penagalaman. Dari beberapa pendapat para ahli diatas dapat disimpulkan bahwa kognitif adalah suatu proses berpikir, yaitu kemampuan individu untuk menghubungkan, menilai, dan mempertimbangkan seuatu kejadian atau peristiwa. Kemampuan kognitif ini berkembang secara bertahap sejalan dengan perkembangan fisik dan saraf.

Melalui nyanyian atau lagu, banyak hal yang dapat kita pesankan kepada anak, terutama pesan-pesan moral dan nilai-nilai agama. Dengan kegiatan bernyanyi, suasana belajar anak akan lebih menyenangkan, dan anak merasa terhibur dan menjadi lebih semangat dengan bernyanyi potensi belahan otak kanan lebih dioptimalkan, sehingga pesan-pesan yang kita berikan akan lebih lama bertahan dimemori anak (ingatan jangka panjang).

Sudah pernah dilakukan kegiatan seperti anak diajarkan untuk bernyanyi menyebutkan nama-nama benda dalam bahasa inggris ataupun bahasa arab, setelah beberapa hari anak diberi perintah untuk menyebutkan kembali beberapa benda, dan anak masih mengingat dan menyebutkan benda tersebut dengan lancar.

Dalam pengembangan kognitif banyak sekali kegiatan yang dapat dilakukan guru dalam mengembangkan aspek kognitif anak diantarnya dengan kegiatan bernyanyi. Pengaruh metode bernyanyi untuk perkembangan kognitif anak sangat berdampak karena memiliki manfaat yang sangat penting bagi anak, selain itu pada aspek perkembangan lainnya seperti bahasa, seni fisik motorik maupun sosial emosional

Di masa pandemi kegiatan pembelajaran dilaksanakan di rumah ini diwajibkan anak untuk belajar dirumah. Pendidik dan orang tua diharapkan bekerja sama agar pembelajaran tetap berlangsung dengan efektif. Pendidik dituntut mampu membuat rencana pembelajaran jarak jauh namun tetap efektif. Salah satu metode yang selalu digunakan pada Pendidikan anak usia dini yaitu 
metode bernyanyi. Bernyanyi adalah salah satu cara yang tepat untuk mengembangkan kemampuan anak usia dini sesuai kompetensinya. Melalui bernyanyi, anak memperoleh banyak informasi mengenai hal-hal baru dan berlatih melalui keterampilan yang ada.

Dengan metode bernyanyi anak akan lebih mudah mengingat sesuatu, karena dengan adanya nada yang enak didengar bagi anak akan membuat anak menjadi semangat untuk belajar, bernyanyi juga akan membuat memori di otak anak menjadi lebih kuat dan tidak mudah lupa, maka dari itu pembelajaran bernyanyi pada masa pandemi ini sangat penting untuk ditanamkan bahkan harus menjadi kebiasaan anak. Mengingat anak tidak bisa berinteraksi dengan teman sekitar dan diharuskan untuk belajar bersama orangtua dirumah, dan bernyanyi menjadi solusi yang bagus ketika anak sedang bosan dengan pembelajaran yang dilakukan dirumah.

Manfaat penelitian ini adalah membantu anak - anak dalam belajar kosa kata dan informasi baru dengan cara yang menyenangkan dan mudah. Tujuan penelitian ini yaitu memaparkan peningkatan kognitif anak ketika menggunakan metode benyanyi untuk menghafalkan kosa kata baru bahkan dengan bahasa asing.

Metode bernyanyi sangat efektif dilakukan mengingat pada masa pandemi seperti ini, anak akan merasa bosan dan tidak semangat untuk belajar, maka bernyanyi bisa menjadi kegiatan yang menyenangkan bagi anak karena bernyanyi memberikan perasaan yang semangat.

\section{METODE}

Penelitian menggunakan metode non eksperimental dari observasi hasil belajar anak. Penelitian ini dilaksanakan di RA Sunan Ampel Pasuruan selama 2 bulan. Selama masa pandemi, pembelajaran dilaksanakan secara daring sehingga penggunaan media ini dilakukan dengan cara guru mengirim dua video melalui grup aplikasi WhatsApp berupa satu video berisikan gambar benda-benda dalam kelas dan penyebutan namanya dalam Bahasa Inggris dan Bahasa Indonesia tanpa dilagukaan, serta satu video lainnya berisi gambar benda-benda dalam 
kelas dengan nama benda dalam Bahasa arab dan Bahasa Indonesia yang dilagukan. Guru memberikan tugas anak untukmenyebutkan nama-nama benda dalam bahasa arab dan juga bahasa inggris supaya anak lebih mengenal tentang bahasa-bahasa asing, dan akan selalu diingat anak jika menggunakan lagu yang menarik. Penggunaan kedua video tersebut sebagai perbandingan kemampuan kognitif anak. Video tersebut diberikan pada hari Senin 7 September 2020, dan pengumpulan tugas dimulai pada hari Jumat 11 september 2020 berupa video atau pesan suara anak didik yang sedang menyanyikan dan menyebutkan kosa kata sebagaimana di video pembelajaran.

Dari waktu yang telah ditentukan beberapa anak mengumpulkan tugas sesuai jadwal pada hari jumat, dan juga ada siswa yang telat mengumpulkan tugas beberapa hari setelah jadwal yang sudah ditentukan. Beberapa juga mengumpulkan tugas pada akhir waktu yaitu pada pukul 20.00, dikarenakan faktor pekerjaan orangtua yang tidak bisa mendampingi anak untuk belajar dan mengumpulkan tugas tepat waktu

\section{HASIL DAN PEMBAHASAN}

Sudjana dalam Nana menjelaskan bahwa berhasil atau tidaknya proses belajar mengajar dapat dilihat dari hasil belajarnya. Hasil proses belajar tersebut dapat dinilai melalui evaluasi hasil belajar. Klasifikasi hasil belajar, secara garis besar dibagi menjadi tiga ranah, yaitu: (1) ranah kognitif, (2) ranah afektif, (3) ranah psikomotor. Penugasan menghafal kosa kata masuk dalam ranah kognitif, kemampuan kognitif anak dapat dinilai dari seberapa cepat mereka mengingat hal-hal baru. Maka dari itu kami mengelompokkan kemampuan kognitif anak berdasarkan waktu pengumpulan tugas.

Bernyanyi digunakan sebagai teknik dalam proses pembelajaran. Lagu yang memiliki elemen didalamnya dapat dijadikan salah satu bentuk fasilitas untuk mengembangkan kemampuan kognitif anak. tinggi nada memberikan kesempatan kepada anak untuk melatih kepekaan pendengarannya. Perubahan ritme melatih anak untuk membedakan irama serta kemampuan motoriknya (misalnya, jika di kombinasikan dengan latihan gerak sesuai dengan liriknya). Secara umum bernyanyi bagi anak lebih berfungsi sebagai aktivitas bermain dari 
pada aktivitas bermain dari pada aktivitas pembelajaran atau penyampaian pesan. Selain itu kemampuan anak dalam menyimak dan mendengarkan ataupun berkrreativitas dapat dilatih dan juga dikembangkan melalui kegiatan bernyanyi.

Bernyanyi merupakan kegiatan yang penting dalam pembelajaran karena dapat menjadikan siswa lebih sensitif terahadap bunyi-bunyian. Saat anak menyukai lagu yang dicontohkan oleh guru, mereka akan dengan senang hati dan antusias melakukannya. Dan saat itulah, secara tidak langsung mereka tengah mempelajari sesuatu dan menambah pengalaman bernyanyinya. Pemilihan metode bernyanyi yang sesuai dapat menciptakan suasana belajar yang menyenangkan. Lebih dari itu, kata-kata yang digunakan dalam lagu anak cenderung lebih sederhana sehingga dapat memudahkan anak untuk mempelajari lagu sesuai yang dicontohkan.

Metode bernyanyi merupakan metode yang menggunakan unsur seni yang digemari oleh anak-anak. dalam kegiatan pembelajaran pada anak usia dini bernyanyi merupakan kegiatan yang harus ada di setiap pembelajaran, bahkan bernyanyi seolah-olah menjadi kegiatan yang wajib dilakukan.

Pembelajaran anak usia dini harus menyesuaikan karakteristik pada anak, yaitu menggunakan pembelajaran yang menyenangkan, bernyanyi adalah contoh kgeiatan yang menyenangkan bagi anak, menggunakan metode bernyanyi akan sangat menarik perhatian anak, sesuai dalam teori belajar behavioristik bahwasannya agar hasil belajar sesuai dengan yang diinginkan dan dibutuhkan stimulus atau pembelajaran secara berulang-ulang.dalam kegiatan bernyanyi pun dapat meningkatkan aspek perkembangan lainnya seperti meningkatkan kemampuan berpikir, perkembangan bahasa, perkembangan fisik dan juga , motorik anak, selain itu dapat meningkatkan rasa kepercayaan diri anak untuk tampil didepan orangtuanya.

Tantranurandi yang mengungkapkan bahwa metode bernyanyi merupakan suatu metode yang melafalkan suatu kata/kalimat yang dinyanyikan. Dalam jurnal Elisabeth nyanyian berfungsi sebagai alat untuk mencurahkan pikiran dan perasaan untuk berkomunikasi. Pada hakikatnya bernyanyi bagi anak-anak adalah sebagai berikut: 
1. Bahasa emosi, dimana dengan nyanyian anak dapat mengungkapkan perasaannya, rasa senang, lucu, dan kagum

2. Bahasa nada, karena nyanyian dapat digelar dapat dinaynyikan, dan dikomunikasikan

Bernyanyi juga harus di sesuaikan dengan dengan materi pembelajaran yang sedang berlangsung, apabila sesuai maka disamping menghibur suasana hati anak, menyanyi juga dapat menguatkan pemahaman terhadap materi yang sedang diajarkan.

Menurut Syamsuri Jari, sebagaimana dikutip oleh Setyowadi, menyebutkan bahwa diantara manfaat penggunaan lagu (menyanyi) dalam pembelajaran adalah sebagai berikut:

1. Sarana relaksasi dengan menetralisasi denyut jantung dan gelombang otak

2. Menumbuhkan minat dan mneguatkan daya Tarik pembelajaran

3. Menciptakan proses pembelajaran lebih humanis dan menyenangkan

4. Sebagai jembatan dalam mengingat materi pembelajaran

5. Mendorong motivasi belajar siswa

Menurut Bomie dan John terdapat manfaat dari metode menyanyi yaitu membantu mencapai kemampuan dalam pengembangan daya pikir, membantu menyalirkan emosi seperti senang atau sedih. Selalin metode bernyanyi memiliki manfaat lebih bagi anak yaitu, anak mampu untuk membantu mengembangkan, memperperbanyak kesiapan serta penguasaan keteramplan dalam proses kognitif atau pengenalan siswa. Memberikan kesempatan kepada anak untuk untuk berkembang dan maju sesuai dengan kemampuan masing-masing, serta mampu mengarahkan cara belajar siswa, sehingga lebih memiliki motivasi untuk lebih giat dan semangat untuk belajar.

Menurut Novan Ardy Wiyana dan Burnawi, tujuan bernyanyi adalah:

1. Membuat suasan pembelajarn menjadi lebih menyenangkan, sehingga kita dapat mneyampikan pesan-[esan kepada anak melalui bernyanyi, terutama pesan-pesan moral agama

2. Membuat anak bahagia 
3. Membuat anak lebih bersemangatdalam belajar, sehingga pesan-pesan yang kita sampaikan akan lebih mudah dan lebih cepat dielterima ole setiap anak.

Adanya kegiatan bernyanyi di pendidikan anak usia dini bertujuan sebagai berikut:

1. Anak dapat mendengar dan menikmati nyanyian

2. Anak mendapatkan rasa sensing ketika bernyanyi

3. Anak dapat mengungkapkan pikiran san suasana hatinya

4. Anak akan belajar bagaimana mengendalikan suara

5. Dapat menambah perbendaharaan kata dalam nyanyian anak

Selain tujuan bernyanyi adapun beberapa manfaat bernyanyi bagi anak sebagai berikut

1. Meningkatkan semangat anak dalam belajar

Apersepsi dalam pembelajaran banyak yang menggunakan kegiatan bernyanyi dengan nada yang semangat dan ceria. Pada saat anak menyenyaikan lagu yang ceria maka emosi anak akan menyesuaikan dengan lagu yang sedang ia nyanyikan dan bisa mengubah suasana hati anak menjadi lebih baik.

2. Anak akan mudah mnegingat atau menghafal materi pembelajaran

Kegiatan bernyanyi dapat membantu perkembangan daya menginghat anak, hal itu telihat pada saat guru menggunakan metode bernyanyi untuk menghafalkan nama-nama benda yang ada dikelas menggunakan bahasa inggris dan juga bahasa arab.

3. Bernyanyi dapat meningkatkan rasa kepercayaan diri anak

Ketika guru memberikan tugas untuk menghafal lagu dalam bahasa inggris dan juga bahasa arab, orangtua akan membimbing anak untuk menghafalkan nama benda yang ada dikelas satu persatu, setelah menghafal semuanya, anak akan akan direkam video oleh orangtuanya untuk dikirimkan ke grup whatsapp hingga guru dapat memberikan nilai kepada anak untuk hafalan lagu tersebut. 
4. Bernyanyi dapat mengembangkan motorik anak

Banyak sekali lagu-lagu yang ceria dan semangat, ketika anak mendengarkan lagu-lagu ceria anak kana menyeseuiakn gerakan tubuhnya untuk mengikuti alunan melodi dar lagu tersebut. Anak akan mneggerakan tangan, kaki, ataupun kepalanya, hal ini dapat mengembangkan otot besar dan kecil anak.

5. Bernyanyi dapat mengembangkan rasa humor anak

Syair-syair lagu yang lucu dan jenaka dapat menumbuhkan rasa humor anak.

6. Bernyanyi dapat mengembangkan keterampilan berpikir anak

Hal ini dilakukan dengan meminta anak untuk mnejawab pertanyaan berkaitan dengan nama-nama benda yang ada dikelas, dan anak menjaab menggunakan bahasa inggris ataupun bahasa arab.

Proses kognitif menurut Mirroh Fikriati, adalah proses manusia untuk memperoleh pengetahuan tentang dunia, yang meliputi proses berpikir, belajar, menangkap, mengingat, dan memahmi. Sedangkan menurut Wowo Sunaryo Kuswana, proses kognitif merupakan gabungan anatar informasi yang diterima melalui indera tubuh manusia dengan informasi yang telah ada.

Menurut Taufik Pasiak (2006) bernyanyi atau bermain musik mampu melatih seluruh bagian otak secara maksimal, sebab ketika mendengarkan semua musik, lagu atau nyanyian, otak akan memproses lirik lagu yang didengan atau dinyanyikan. Kamtini (2005), /mengemukakan "bernyanyi merupakan sarana pengungkapan pikiran dan perasaan, sebab kegiatan bernyanyi adalah kegiatan yang menyenangkan yang memberi kepuasan kepada anak-anak.

Bernyanyi atau mendengarkan suara musik adalah bagian dari kebutuhan anak. melalui nyanyian atau lagu, kemampuan anak akan berkembang. Bernyanyi dapat dilakukan dengan berbagai bentuk seperti:

a. Bernyanyi pasif, anak hanya mendengarkan suara nyanyian atau musik dan menikmati tanpa terlibat langsung dalam kegiatan bernyanyi. 
b. Bernyanyi aktif, melakukan langsung kegiatan menyanyi, baik dilakukan sendiri ataupun mengikuti contoh nyanyian.

Ketika guru memberikan tugas bernyanyi menyebutkan nama-nama benda dengan bahasa arab dan juga bahasa inggris, anak sangat antusias dan bersemangat ketika menyanyikan. Dan waktu pengumpulan tugas sangat beragam dikarenakan jam kerja orangtua.

Tabel 1. Data Pengumpulan Tugas Anak

\begin{tabular}{lcc}
\hline Waktu Pengumpulan & $\begin{array}{c}\text { Kosa kata Bahasa arab } \\
\text { (lagu) }\end{array}$ & $\begin{array}{c}\text { Kosa kata Bahasa inggris } \\
\text { (tanpa lagu) }\end{array}$ \\
\hline $\begin{array}{l}\text { Hari pertama } \\
\text { Jumat, 11 September } 2020\end{array}$ & 7 anak & 3 anak \\
\hline Hari kedua & 3 anak & 13 anak \\
Sabtu, 12 September 2020 & & 16 anak \\
\hline Hari selanjutnya & 6 anak & \\
\hline Total siswa & 16 anak &
\end{tabular}

Waktu pengumpulan tugas mulai pukul 07.00 hingga 24.00 WIB. Faktorfaktor bevariasinya pengumpulan tugas dikarenakan pengumpulan tugas di grup WhatsApp dilakukan oleh wali murid dimana para para wali murid memiliki pekerjaan yang berbeda-beda. Beberapa menjadi ibu rumah tangga dan beberapa lagi bekerja dengan jam kerja tertentu. Atas dasar inilah kami mengkategorikan waktu pengumpulan menjadi tiga kategori yaitu hari pertama, hari kedua, dan hari selanjutnya. Hari selanjutnya merupakan pengumpulan tugas di hari ketiga hingga seterusnya, karena masih ada pengumpulan tugas di hari keempat dan kelima.

Pengumpulan tugas di hari pertama mengindikasikan anak dapat menghafal kosa kata bahasa asing dengan cepat walau penyebutan 1-3 kata kurang sempurna. Hal ini dikarenakan beberapa anak hanya mengahafalkan kosa kata melalui apa yang ia dengar, bukan berdasarkan apa yang dibaca dan hal ini menyebabkan elevise atau salah dengar yang akhirnya menyebabkan salah pengucapan pula. Hal ini dapat dimaklumi karena beban tugas anak bukan hanya hafalan kosa kata, tetapi juga ada tugas menulis dan mewarnai ynag harus dikumpulkan di hari yang sama. 
Pengumpulan tugas di hari kedua mengindikasikan anak dapat menghafal kosa kata bahasa asing walaupun sedikit lambat dengan penyebutan 1-3 kosa kata kurang sempurna. Pengumpulan tugas yang terlambat juga bisa disebabkan wali murid yang baru sempat mengirimkan tugas di hari esoknya walaupun anak telah hafal d hari pertama.

Pengumpulan tugas di hari selanjutnya mengindikasikan anak kurang mampu menghafal kosa kata Bahasa asing elevis beberapa kosa kata yang kurang sempurna penyebutannya.

Dari keseluruhan 15 anak kelas B4, 7 anak mengumpulkan video atau pesan suara lagu Bahasa arab di hari pertama, 3 anak di hari kedua, dan sisanya di hari-hari selanjutnya. Sedangkan tugas hafalan Bahasa Inggris baru mulai dikumpulkan di hari kedua oleh 3 anak, dan sisanya di hari-hari berikutnya.

Pada hari ketiga, ada satu anak yang mengumpulkan tugas hafalan Bahasa inggris namun dengan dilagukan. Ibu dari anak tersebut berinisiatif melagukan kosa kata-kosa kata tersebut, dimana anak ini telah mengumpulkan tugas lagu bahasa arab di hari pertama.

Dapat diartikan bahwa ada 7 anak di hari pertama yang dapat menghafal kosa kata bahasa arab dengan cepat walau penyebutan 1-3 kata kurang sempurna. Sedangkan belum ada sama sekali anak yang menghafal kosa kata bahasa inggris di hari pertama. Perbedaan penugasan terseut ada pada kosa kata-kosa kata bahasa arab dilagukan, sedangkan kosa kata-kosa kata bahasa Inggris tidak dilagukan. Padahal dalam keseharian, bahasa inggris lebih sering ditemui di lingkungan sekitar dari pada bahasa arab. Seperti contoh dalam video game, televise, dan video platform tertentu yang mudah diakses anak belakangan ini.

Suyanto (2008) kecerian yang dirasakan oleh anak-anak juga bisa dituangkan dalam lagu, semua anak mneyukai bernyanyi walaupun termasuk anak yang pemalu untuk bernyanyi. Karena sekalipun malu tanpa disadari mereka secara tidak langsung telah mengenal kata baru dalam bahasa yang sedang ia nyanyika. Dengan menyanyikan lagu yang anak sukai maka dapat memberikan kepuasan, kegembiraan, dan kebahagiaan bagi anak sehingga mendorong anak untuk belajar lebih giat. 
Metode bernyanyi ini berhubungan dengan kemampuan untuk menyerap isi dari lagu yang dinyanyikan anak, yang dapat merangsang kreativitas dan perkembangan kognitif anak, namun juga kecerdasan verbal dan kecerdasan emosi, kecerdasan verbal dapat ditemukan dari kosak kata yang terdapat dalam lirik lagu yang dinyanyikan anak, sedangkan kecerdasan emosi lebih kepada anak akan berlatih mengendalikan emosi saat menyanyikan lagu. Sehingga dalam kreativitas yang diciptakan melalui nyanyian tersebut dapat menumbuhkan kesenangan tersendiri bagi anak.

\section{PENUTUP}

\section{Simpulan}

Pengumpulan tugas bernyanyi diberikan waktu 1 minggu, sehingga anak harus membagi wkatu untuk mengerjakan tugas yang sudah ada pada hari itu, peran orangtua sangat penting dalam mengajarkan anak untuk mneghafalkan lagu dalam bahasa inggris dan juga bahasa arab, mengingat pekerjaan orangtua yang berbeda dan juga waktu yang disempatkan untuk memberikan mengajarkan pada anak. beberapa anak sudah mengumpulkan dan menyetorkan video hafalan melaului whatsApp dari jadwal yang sudah ditentukan. Sehingga bisa dilihat bahwa metode bernyanyi sangat efektif dilakukan dalam pembelajaran anak. Berdasarkan pembahasan dan hasil penelitian dapat disimpulkan bahwa anak lebih cepat menghafal kosa kata baru degan bernyanyi dari pada menghafal kosa kata baru dengan hanya disebutkan tanpa nada (bukan bernyanyi). Dimana kecepatan menghafal masuk ke ranah kognitif.

Metode bernyanyi bisa diterapkan untuk meningkatkan kosakata anak dikarenakan bernyanyi merupakan kegiatan sangat dekat dengan anak dan dap;at meningkatkan semangat siswa. Diharapkan dengan adanya penelitian ini baik orang tua maupun guru dapat berinisiatif membuat lagu untuk pembelajaran yang lebih efektif terutama saat memperkenalkan hal-hal baru. 


\section{DAFTAR PUSTAKA}

Badriyah, Saidatul. 2012. Pengaruh Metode Bernyanyi Terhadap Peningkatan Kosakata Bahasa Arab Pada Anak TPQ Wardtaul Islah Merjosari Malang, malang: Universitas Islam Negeri Maulana Malik Ibrahim

Dhien, Laura. 2009. Meningkatkan Kemampuan Berbicara Anak. Jakarta: PT Bhuana Ilmu Populer Kelompok Gramedia.

Jamaris Martini, 2006. Perkembangan dan pengembangan Anak Usia Taman Kanakkanak. Jakarta: Grasindo

Jamaris, Martini. 2008. Perkembangan dan Pengembangan Anak Usia Taman Kanakkanak. Program Studi Pendidikan Anak Usia Dini: UNJ.

Kamtini, dkk. 2005. Bermain Melalui Gerak dan Lagu di Taman Kanak-kanak. Jakarta: Departemen Pendidikan Nasional.

Masitoh, dkk, 2007. Strategi Pembelajaran TK. Jakarta. Universitas Terbuka.

Nana. 2019. Upaya Peningkatan Kemampuan Kognitif dan Komunikasi Ilmiah Siswa Kelas X MIA 1 SMA Negeri 1 Ciamis Menggunakan Model Pembelajaran Inquiry. Diffraction 1 (10. Hlm 2.

Permendikbud No. 137 Tahun 2014 Tentang Standar Nasional Pendidikan Anak Usia Dini.

Samba, Sojono. 2006. Lebih Baik Tidak Sekolah. Yogyakarta. Lkis.

Undang-undang No. 20 Tahun 2003 tentang Sistem Pendidikan Nasional.

Wijaya, A. Cece. 1992. Kemampuan Dasar guru dalam Proses Belajar Mengajar. Bandung: PT. Remaja Rosdakrya

Khafifah, N. R. 2020. Meningkatkan Perkembangan Kognitif Dengan Metode Bernyanyi Pada Anak Usia Dini. https://doi.org/10.31219/osf.io/kewy3

Nuraeni, N. 2014. Strategi Pembelajaran Untuk Anak Usia Dini. Prisma Sains : Jurnal Pengkajian Ilmu Dan Pembelajaran Matematika Dan IPA IKIP Mataram, 2(2), 143. https://doi.org/10.33394/j-ps.v2i2.1069 